\title{
Dietary Habits among Patients with Kidney Stones: A Retrospective Study
}

\author{
Asmaa Abd El Samie Amin ${ }^{1}$, Nagat El Morsy Ibrahim², Asmaa Diab Abd El Fatah \\ Hassan $^{3}$, El Sayed Mahmoud Hammad ${ }^{4}$ \\ ${ }^{I}$ Clinical instructor of Medical Surgical Nursing, ${ }^{2}$ Assist. Prof. of Medical Surgical Nursing ${ }^{3}$ Lecturer of \\ Medical Surgical Nursing, ${ }^{4}$ Lecturer of nutrition \\ ${ }^{1,2,3}$ Faculty of Nursing-Cairo University- Egypt \\ ${ }^{4}$ Clincal nutrition department-National Nutrition Institute-Egypt
}

\begin{abstract}
: kidney stone disease is considered the most common disorder of the urinary system that forms when the urine becomes supersaturated with specific salts. Fluids and foods consumption have been reported to be associated with incidence and recurrence of kidney stones. Therefore the current study was conducted to assess the dietary habits among patients with kidney stones. A convenient sample of 150 adult patients diagnosed with kidney stones attending the urology department affiliated to El-Kasr El-Ainy hospital in Cairo governorate was recruited to fulfill the aim. Retrospective descriptive research design was conducted to achieve the aim of the present study by using, by using, demographic and medical data tool, dietary habits assessment tool and food frequency questionnaire tool. The study result revealed that (71.3\%) were males, and (28.7\%) were females and

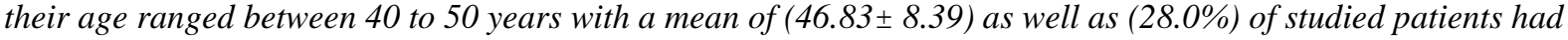
recurrence of kidney stone once, (18.7\%) had stone recurrence twice and (56.7\%) were overweight. There was statistically significant difference between kidney stone and highest intake of animal protein sources, cereals .grains consumption, as well as lowest water intake and highest caffeine drinks consumption. Based on the findings, it can be concluded that, awareness about the dietary and fluid consumption is essential and helpful in treatment of kidney stones.
\end{abstract}

Keywords: Dietary habits, kidney stone.

\section{Introduction}

Kidney stone disease is considered a third most common disorder of the urinary system. It has been known for thousands years but in recent years the incidence of kidney stone has been increased [1]. Dramatic changes in dietary habits are one of the major causes of an increased incidence of kidney stone in recent years [2]. Kidney stone forms when the urine becomes supersaturated with specific salts such as calcium, oxalate, uric acid, or cystine. Super saturation of urine results in formation of small crystals that grow and aggregate to form a solid piece called stone [3]. Its formation results from a combination of causes, rather than a single, welldefined cause. Among several others, dietary habits are one of several factors that affect on kidney stone formation and its recurrence [4].

Dietary habits have a great influence on the concentration of excreted salts, either promote or inhibit the stone formation. Certain diet may promote stone formation in people who are susceptible. Dietary habits that include a high intake of salts, animal proteins and oxalates and a low intake of calcium and fluids have been evaluated for their effect on stone formation and recurrence. The change of inappropriate habitual diet patterns should be the main measure to prevent kidney stone. Kidney Stones also commonly have been found in those that drink less than the recommended of fluids especially water intake per day [5].

Kidney stone disease is rarely asymptomatic. When it is small, it may pass on its own without pain. However, large stone may block urine flow, which can cause a sever flank pain. It is often described as one of the strongest pain sensations known. Early diagnosis is important for immediate treatment to decrease the morbidity and complication rate. In the diagnosis of kidney stone, dietary and medical history must be carefully identified [6].

Nurses as health care provider have a definitive role in doing a dietary plan for patients with kidney stones to keep a healthy diet and prevent the stone recurrence [7]. Improved awareness and education among both patients and health-care providers about risk factors of kidney stones has the potential to improve general health and decrease morbidity and mortality caused by kidney-stone disease [8].

Therefore, the researchers were interested to conduct this current study to assess the dietary habits among patients with kidney stones. 


\subsection{Significance of the study}

The rise of kidney stone incidence is a global phenomenon. Between $1 \%$ and $15 \%$ of people globally are affected by kidney stones at some point in their life [9]. Kidney stone disease is common and rises in the Middle East. A high prevalence of disease is commonly seen in countries such as Egypt, Saudi Arabia and Pakistan. It is suggested that a high temperature, inadequate fluid intake and low urine volume predispose to stone formation in these areas [10].

Recurrence rate of kidney stone is also most common. Stones recurrence worldwide rate is approximating $50 \%$ in 5 to 10 years and $75 \%$ in 20 years [11]. Recurrent stone causes not only pain and distress in those affected but also has a significant health care load in a working- population. Recent studies suggest rising utilization of health care resources for treating patients with kidney stone disease [12].

Stone that formed May blockage flow of urine through its normal path and cause blood flow to be redistributed to the opposite renal artery. A transient increase in serum creatinine may follow this decrease in the glomerular filtration rate. Prolonged obstruction impairs recoverable kidney function over time. Patients with kidney stones may have a life-threatening complication [13]. It is significantly associated with increased risk of chronic kidney disease (CKD) if the effective preventive and therapeutic measures weren't taken [14]. In Iran, the prevalence of end stage of renal disease (ESRD) due to kidney stones among patients who start maintenance hemodialysis was approximately $3.2 \%$ [15].

\section{Material and Methods}

The current study aims to assess the dietary habits among patients with kidney stones. With this in mind, the following research questions were postulated:

1 -What are the dietary habits among patients with kidney stones?

2 -Is there a relationship between the dietary habits \& kidney stones formation?

\subsection{Design}

Retrospective descriptive research design was utilized in the current study. A retrospective research looks backwards and examines exposures to suspected risk or protection factors in relation to an outcome that is established at the start of the study [16]. Descriptive research helps researchers, plans and carries out descriptive studies, designed to provide rich descriptive details about people places and other phenomena [17].

\subsection{Setting}

This study conducted only at the urology department affiliated to El- Kasr El-Ainy hospital. This department was located in the second floor and divided in one ward and two rooms for males and another five rooms for females. This department is a surgical specialty which deals with disorders of the urinary tract.

\subsection{Sample:}

A convenient sample of 150 adult male and female patients diagnosed with kidney stone was included in this study. Those who had medical disorder such as hyperparathyroidism, ureteral stricture, hypertension, Diabetes were excluded. The size of the sample was calculated by power analysis of $95(\beta=1-.95=.5)$ at alpha .05 (one-sided) with confident level 95\% [18].

\subsection{Data collection tools:}

The investigators used three tools to gather data pertinent to the study as follows:

2.4.1. Structured interview questionnaire was developed by the investigators. This tool consisting of two parts: First part: includes demographic data covering questions related to age and gender. Second part: covered the medical related data includes questions related to recurrence rate of kidney stone and body mass index.

2.4.2. This tool was formulated after extensive literature review [19], [20] and seeking expert's advice. It includes 15 questions used to assess eating habits and provide with information about numbers of meals, main meal, snakes, usually cooking methods, kind of fat used during cooking........ect.

2.4.3. Food frequency questionnaire tool, this tool structure was constructed based on [21] and modified by investigator for accommodating with common foods and drinks in Egypt based on [22]. It includes 63questions covered a common foods and drinks in Egypt and divided into categories of diet groups such as intake of animal protein sources include consume sources of protein derived from meat, fish, and poultry, eating cereals. Grains include legumes that derived from rice, pasta, and kosharie. Each participant asked to report the average frequency of foods and drinks (the number of times per day, week, month, and year) that was usually consumed over the last year before onset of kidney stone disease. Each food category was quantified according to its measuring unit. Example, one small banana (100gm), one medium plate of cooked rice (200gm), one teaspoon of table salt $(5 \mathrm{gm})$, one cup of tea $(150 \mathrm{ml})$, one small bottle of cola $(200 \mathrm{ml})$.Then the total mean amount of daily food and drinks consumption for different categories was calculated. 
The Content validity was checked. Reliability of the tools was tested using alpha coefficient test which test-retest the answer of sample for the questionnaire in first time T1and second time (after two weeks) T2 and then calculate the reliability coefficient between the answers of the sample at the both times (T1, T2), which was .94 that considered excellent reliability.

\subsection{Pilot study}

A pilot study was conducted on $10 \%$ of the sample to ensure objectivity, clarity, feasibility, and reliability of the study tool and estimate needed time for data collection. A few modifications were done and the final format was developed. Subjects who shared in the pilot study were included in the actual study.

\subsection{Ethical considerations}

Primary approval was obtained from ethical committee of research at faculty of nursing in Cairo University. Also an official permission was obtained from hospital administrators to conduct the study. Each patient was informed about the purpose of the study and its importance. Each subject has the right to withdrawal from the study when he or she wants. Informed consent was obtained from the subject. Anonymity and confidentiality was assured through coding the data.

\subsection{Procedure for data collection:}

Once official permission was granted to proceed with the study, the investigator performed interview with concerned patients after explaining the nature and purpose of the study at urology department, each participant who are willing to participate in the study was asked to sign the consent form. If he/she can't read and write; one of his or her relatives signs the consent. Then the investigator started to collect demographic and medical related data using (tool I), subsequently the investigator assessed the participant dietary habits using (tool II) and food frequency questionnaire using (tool III). During the visit, any clarification or question was answered by investigator. Time spent with each individual participant was 40-50 minute.

\subsection{Statistical analysis:}

Obtained data was tabulated, computed and analyzed using statistical package for the social science (SPSS) program version 21. Descriptive statistics including frequency, percentage distribution, means and standard deviation, relation between variables using chi-square was utilized. All data entries were checked for accuracy against the original raw data of each patient by the investigator for all statistical tests done. Probability level of 0.01 and 0.05 was adopted as the level of significance.

\section{Results}

Results of the study are presented in two major parts; the first part is descriptive statistics that included the description of the demographic data as age and gender and medical related data such as recurrence rate of kidney stone and body mass index, the second one presents the statistical relation between kidney stone and foods categories/ and drinks consumption among the studied participants who known or unknown their stones type.

Study sample' characteristics: As shown in table (1), (48.7\%) of study participants aged from 40-50 years old with $\mathrm{M} \pm \mathrm{SD}(46.83 \pm 8.39)$, and $(71.3 \%)$ were males.

Table (1): Frequency \& percentage distribution of demographic data among studied participants $(n=150)$.

\begin{tabular}{|l|l|l|}
\hline Variables & N & \% \\
\hline Age & & \\
$-20-<40$ & 29 & 19.3 \\
$-40-50$ & 73 & 48.7 \\
$-51-60$ & 48 & 32.0 \\
$\quad$ M \pm SD 46.83 \pm 8.39 & & \\
\hline Sex & 107 & 71.3 \\
-Male & 43 & 28.7 \\
-Female & & \\
\hline
\end{tabular}

Medical data: illustrated that in fig (1): (53.3\%) of study participants had kidney stone for first time, but $(28.0 \%)$ had repeated kidney stone once and (18.7\%) had repeated kidney stone twice, While fig (2): displayed that $(56.7 \%)$ of the studied participants were overweight, and $(19.3 \%)$ were obese but only $(24.0 \%)$ had normal body weight. 
Recurrence rate of kidney stone $(n=150)$

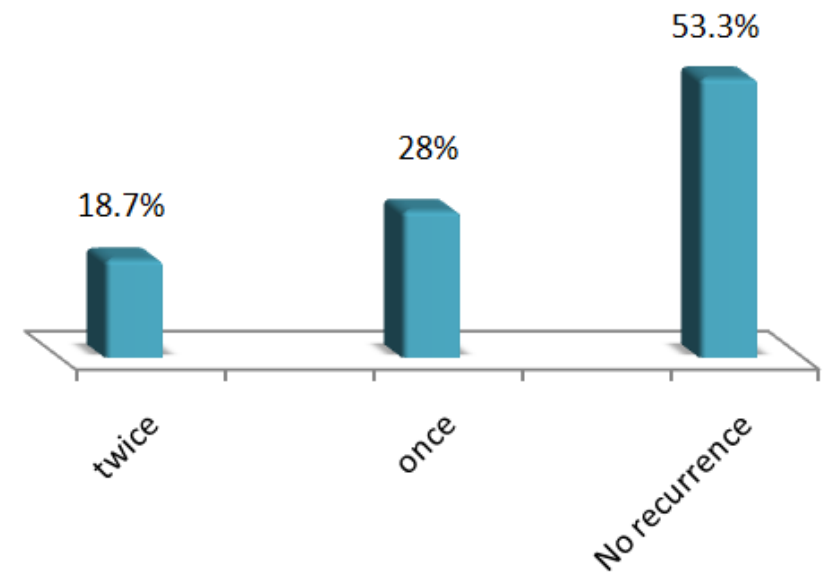

Figure (1): Percentage distribution of recurrence rate of kidney stone among studied participants $(\mathrm{n}=150)$.

\section{BMI $(n=150)$}

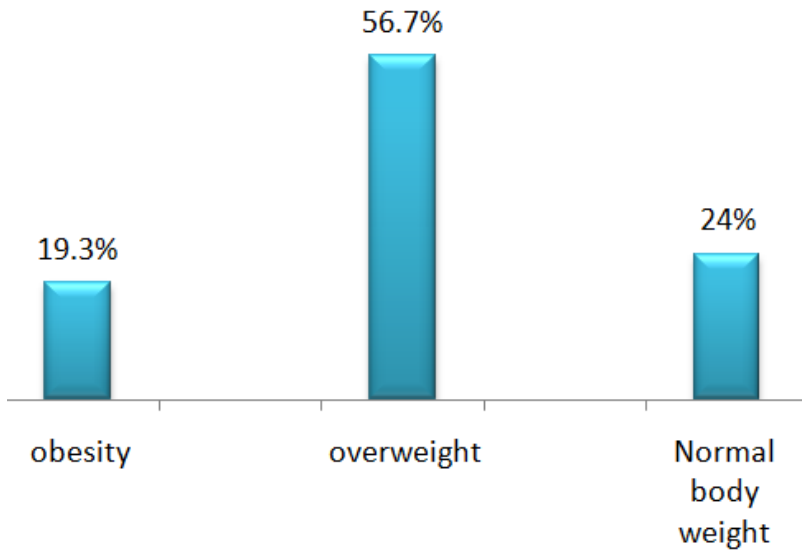

Figure (2): percentage distribution of body mass index (BMI) among studied participants ( $\mathrm{n}=150)$.

Table (2): showed that there was highly statistical significant difference between kidney stone (calcium oxalate, uric acid and unknown stones type) and highest intake of animal protein sources $\left(\chi^{2}=18.272, \mathrm{p}=.000^{* *}\right)$, as well as there was a statistical significant difference with highest intake of cereals . grains consumption $\left(\chi^{2}=8.420, p=\right.$ $.004 *)$, While there was no statistical significant difference between kidney stone and vegetables intake $\left(\chi^{2}=1.496, \mathrm{p}=.473\right)$, also there was no statistical significant difference with fruits consumption $\left(\chi^{2}=1.192, \mathrm{p}=\right.$ $.551)$.

Table (2): Correlation between kidney stone and food categories intake among the studied participants ( $\mathrm{n}=150)$.

\begin{tabular}{|c|c|c|c|c|c|c|c|c|}
\hline \multirow[t]{3}{*}{ Variable } & \multicolumn{6}{|c|}{ Type of kidney stone } & \multirow[t]{3}{*}{$\chi^{2}$} & \multirow[t]{3}{*}{ p. value } \\
\hline & \multicolumn{2}{|c|}{ Calcium oxalate } & \multicolumn{2}{|c|}{ Uric acid } & \multicolumn{2}{|c|}{ Un known } & & \\
\hline & $\mathrm{N}$ & $\%$ & $\mathrm{~N}$ & $\%$ & $\mathrm{~N}$ & $\%$ & & \\
\hline $\begin{array}{l}\text { Animal protein sources } \\
\text {-Low (<50 g/day) } \\
\text {-Moderate }(50-100 \mathrm{~g} / \text { day }) \\
\text {-High ( }>100 \mathrm{~g} / \text { day }) \\
\end{array}$ & $\begin{array}{l}3 \\
25 \\
9 \\
\end{array}$ & $\begin{array}{l}2.0 \\
16.7 \\
6.0 \\
\end{array}$ & $\begin{array}{l}0 \\
1 \\
12 \\
\end{array}$ & $\begin{array}{l}0.0 \\
.7 \\
8.0\end{array}$ & $\begin{array}{l}13 \\
19 \\
68 \\
\end{array}$ & $\begin{array}{l}8.7 \\
12.7 \\
45.3 \\
\end{array}$ & 18.272 & $.000 * *$ \\
\hline $\begin{array}{l}\text { Cereals. Grain Products } \\
\text {-Low }(<120 \text { g/day }) \\
\text {-Moderate }(120-180 \mathrm{~g} / \mathrm{d}) \\
\text {-High }(>180 \mathrm{~g} / \text { day })\end{array}$ & $\begin{array}{l}0 \\
1 \\
36\end{array}$ & $\begin{array}{l}0.0 \\
0.7 \\
24.0\end{array}$ & $\begin{array}{l}0 \\
4 \\
9\end{array}$ & $\begin{array}{l}0.0 \\
2.7 \\
6.0\end{array}$ & $\begin{array}{l}0 \\
12 \\
88\end{array}$ & $\begin{array}{l}0.0 \\
8.0 \\
58.7 \\
\end{array}$ & 8.420 & $.004 *$ \\
\hline $\begin{array}{l}\text { Vegetables } \\
\text {-Low }(<200 \mathrm{~g} / \text { day }) \\
\text {-Moderate }(200-400 \mathrm{~g} / \text { day }) \\
\text {-High }(>400 \mathrm{~g} / \text { day })\end{array}$ & $\begin{array}{l}34 \\
3 \\
0\end{array}$ & $\begin{array}{l}22.7 \\
2.0 \\
0.0\end{array}$ & $\begin{array}{l}12 \\
1 \\
0\end{array}$ & $\begin{array}{l}8.0 \\
.7 \\
0.0\end{array}$ & $\begin{array}{l}82 \\
18 \\
0\end{array}$ & $\begin{array}{l}54.7 \\
12.0 \\
0.0\end{array}$ & 1.496 & $\begin{array}{l}.473 \\
\text { (NS) }\end{array}$ \\
\hline
\end{tabular}


Dietary habits among patients with kidney stones: A Retrospective study

\begin{tabular}{|l|l|l|l|l|l|l|l|l|}
\hline Fruits & & & & & & & & \\
-Low (<200g/day) & 30 & 20.0 & 8 & 5.3 & 81 & 54.0 & 1.192 & .551 \\
-Moderate (200-400g/day) & 7 & 4.7 & 5 & 3.3 & 19 & 12.7 & & (NS) \\
-High (>180g/day) & 0 & 0.0 & 0 & 0.0 & 0 & 0.0 & & \\
\hline
\end{tabular}

**Highly significance $\quad *$ Significance $\quad(\mathrm{NS})$ : not significance

Table (3): $\left(\chi^{2}=1.954, \mathrm{p}=.0 .744\right)$, as well as with fruit juices $\left(\chi^{2}=1.732, \mathrm{p}=.421\right)$. revealed that there was statistical significant difference between kidney stone (calcium oxalate, uric acid, unknown stones types) and lowest water intake $\left(\chi^{2}=3.723, \mathrm{p}=.038^{*}\right)$, as well as with highest consumption of caffeine drinks $\left(\chi^{2}=9.436\right.$, $\left.\mathrm{p}=.002^{* *}\right)$. The table also, revealed there was no statistically significant difference between kidney stone and Soft drinks consumption

Table (3): Correlation between kidney stone and fluid consumption among the studied participants $(\mathrm{n}=150)$.

\begin{tabular}{|c|c|c|c|c|c|c|c|c|}
\hline \multirow{3}{*}{ Variable } & \multicolumn{6}{|c|}{ Type of kidney stone } & \multirow{3}{*}{$\chi^{2}$} & \multirow{3}{*}{ p. value } \\
\hline & \multicolumn{2}{|c|}{ Calcium oxalate } & \multicolumn{2}{|c|}{ Uric acid } & \multicolumn{2}{|c|}{ Un known } & & \\
\hline & $\mathrm{N}$ & $\%$ & $\mathrm{~N}$ & $\%$ & $\mathrm{~N}$ & $\%$ & & \\
\hline $\begin{array}{l}\text { Daily water intake } \\
\text {-Low }(<1500 \mathrm{ml} / \text { day }) \\
\text {-Moderate }(1500-2000 \mathrm{ml} / \text { day }) \\
\text {-High }(>2000 \mathrm{ml} / \text { day })\end{array}$ & $\begin{array}{l}36 \\
1 \\
0 \\
\end{array}$ & $\begin{array}{l}24.0 \\
0.7 \\
0.0 \\
\end{array}$ & $\begin{array}{l}11 \\
2 \\
0 \\
\end{array}$ & $\begin{array}{l}7.3 \\
1.3 \\
0.0 \\
\end{array}$ & $\begin{array}{l}65 \\
35 \\
0 \\
\end{array}$ & $\begin{array}{l}43.3 \\
23.3 \\
0.0 \\
\end{array}$ & 3.723 & $.038^{*}$ \\
\hline $\begin{array}{l}\text { Caffeine drinks(coffee and tea) } \\
\text {-Low }(<200 \mathrm{ml} / \text { day }) \\
\text {-Moderate }(200-400 \mathrm{ml} / \text { day }) \\
\text {-High }(>400 \mathrm{ml} / \text { day })\end{array}$ & $\begin{array}{l}0 \\
13 \\
24 \\
\end{array}$ & $\begin{array}{l}0.0 \\
8.7 \\
16.0 \\
\end{array}$ & $\begin{array}{l}0 \\
2 \\
11 \\
\end{array}$ & $\begin{array}{l}0.0 \\
1.3 \\
7.3 \\
\end{array}$ & $\begin{array}{l}16 \\
14 \\
70 \\
\end{array}$ & $\begin{array}{l}10.7 \\
9.3 \\
46.7 \\
\end{array}$ & 9.436 & $.002 *$ \\
\hline $\begin{array}{l}\text { Soft drinks } \\
\text {-Low }(<100 \mathrm{ml} / \text { day }) \\
\text {-Moderate }(100-200 \mathrm{ml} / \text { day }) \\
\text {-High }(>200 \mathrm{ml} / \text { day })\end{array}$ & $\begin{array}{l}33 \\
4 \\
0\end{array}$ & $\begin{array}{l}22.0 \\
2.7 \\
0.0\end{array}$ & $\begin{array}{l}12 \\
0 \\
1\end{array}$ & $\begin{array}{l}8.0 \\
0.0 \\
0.7 \\
\end{array}$ & $\begin{array}{l}85 \\
13 \\
2\end{array}$ & $\begin{array}{l}56.7 \\
8.7 \\
1.3 \\
\end{array}$ & 1.954 & $\begin{array}{l}0.744 \\
\text { (NS) }\end{array}$ \\
\hline $\begin{array}{l}\text { Fruit Juices } \\
\text {-Low }(<50 \mathrm{ml} / \text { day }) \\
\text {-Moderate }(50-100 \mathrm{ml} / \text { day }) \\
\text {-high }(>100 \mathrm{ml} / \text { day })\end{array}$ & $\begin{array}{l}34 \\
3 \\
0\end{array}$ & $\begin{array}{l}22.7 \\
2.0 \\
0.0\end{array}$ & $\begin{array}{l}13 \\
0 \\
0\end{array}$ & $\begin{array}{l}8.7 \\
0.0 \\
0.0\end{array}$ & $\begin{array}{l}89 \\
11 \\
0\end{array}$ & $\begin{array}{l}59.3 \\
7.3 \\
0.0\end{array}$ & 1.732 & $\begin{array}{l}0.421 \\
\text { (NS) }\end{array}$ \\
\hline
\end{tabular}

*significance (NS): not significance

\section{Discussion}

Regarding the participants' characteristics, it was observed that near half of studied participants were their ages ranged between 40 to 50 years old with mean $(46.83 \pm 8.39)$. More than two thirds of the studied patients were male and near one fifth were female. The current study is congruent with a study demonstrated by [23] who found that the total number of upper urinary tract stone was the highest in middle-aged patients at ages in the 40-49 years and continue to increase until age 60 years in both gender. Another study done by [24] mentioned that calcium oxalate stone and uric acid stone are more common in male than female. As well as a study performed by [25] who reported that kidney stone is formed in men more than women with ratio 2:1.

Regarding to this findings' about medical related data, the current study findings revealed that near one fifth of studied participants had kidney stone recurrence once after first kidney stone. According to a study done by [26] who reported that in effective preventive measures, including specific pharmacological interventions in addition to advice for a change in lifestyle and nutritional habits are major factors for increasing recurrence rate of kidney stone. Moreover a study of [27] reported that the stone recurrence among the studied patients was $50 \%$ at 3 years after first kidney stone.

In relation to body mass index, the current study findings reported that more than one third of studied participants were overweight. This result matched with a study demonstrated by [28] who observed that the majority of studied patients with kidney stone were overweight and also mentioned that increasing risk of kidney stones are associated with increasing BMI. Moreover a study demonstrated by [29] reported that High body mass index (BMI) has been linked to an increased the risk of kidney stones.

Concerning foods consumption, the current study findings reported that there was a highly statistical significant difference between kidney stone incidence (calcium oxalate, uric acid, unknown types) and highest eating of animal protein sources $\left(\chi^{2}=18.272, \mathrm{p}=.000^{* *}\right)$. This study in the same stream with [30] who reported that there is a significant relation between high intake of meat, poultry, fish and kidney stone formation Compared to low intake. Moreover a study done by [31] found that increase animal protein intake are associated with increase excretion of calcium, oxalate, uric acid and decrease excretion of citrate result in risk of stone disease. 
The current study findings also showed that there was statistical significance difference between kidney stone and higher Cereals and grains intake $\left(\chi^{2}=8.420, \mathrm{p}=.004^{*}\right)$. This study at the same line with a case-control study of [20] who found that there was statistical significance difference between highest consumption of grains and kidney stones formation among studied patients and also reported that excessive consumption of grain may increase the total energy intake, which can lead to obesity and indirectly associated with kidney stones. Also a study done by [32] reported that high consumption of grains increases the risk of calcium oxalate stone.

The current study results also revealed that there was no statistical significance difference between kidney stone and vegetables intake $\left(\chi^{2}=1.496, \mathrm{p}=.473\right)$. This study results coincided with a study demonstrated by [4] who reported that the relation between intake of vegetables and the risk of stone formation was equal $(\mathrm{p}=$ .88) which was considered no statistically significant. In contrast with a case-control study performed by [20] found that the majority of studied patients were consuming leafy vegetables more than 3 times per day which was positively associated with stones in both men and women.

The current study results also revealed that there was no statistical significance difference between kidney stone formation and fruits consumption $\left(\chi^{2}=1.192, \mathrm{p}=.551\right)$. This results contradicted with a study of [33] who reported that a relationship between higher fresh fruit intake and decreased risk of incident kidney stone formation type was less than 0.001 was which was considered statistically significant.

Regarding fluids intake, the current study results also revealed that there was statistical significance difference between kidney stones incidence and low water intake $\left(\chi^{2}=3.723, p=.038^{*}\right)$. This result consistent with a study done by [5] who found that there was statistical significant difference between high water intake and reduce risk factors for all types of kidney stone in healthy subjects. Moreover a meta-analysis study done by [34] who reported that intake above two liters of water per day reduced the risk of first kidney stone occurrence by at least $8 \%$ compared to $1500 \mathrm{~mL}$ daily intake, and the highest $(3100 \mathrm{~mL})$ category showed a $26 \%$ reduction of kidney stone risk compared to the reference category $(1500 \mathrm{ml})$.

Related Caffeine intake, which is present in both in coffee and tea, the current study showed that, there was statistical significance difference between kidney stone and coffined drinks intake $\left(\chi^{2}=9.436\right.$, $\mathrm{p}=.002 * *)$. This finding supported by a study of [35] who concluded that there was a significantly association difference between excessive drinking of tea and risk of kidney stone incidence. On other hand a study done by [36] who observed that there was an inverse significance difference between highest coffee intake and risk for kidney stone.

The current study also revealed that there was no statistical significance difference between kidney stone and soft drinks consumption $\left(\chi^{2}=1.954, \mathrm{p}=.0 .744\right)$. This study supported by a study done by [37] found that there was no significant difference between increasing Cola drinks intake and kidney stone formation. While contradicted with [38] who reported that there was statistical significant difference between soft drinks consumption and kidney stone formation.

The current study findings also revealed that there was no statistical significance difference between kidney stone and fruit juices intake $\left(\chi^{2}=1.732, \mathrm{p}=.421\right)$. While a Meta analysis study done by [39] who reported that, there was a significant relation between high consumption of fruit juices and decreased renal stone crystallization.

\section{Conclusion}

Based on results of the current study, it can be concluded that foods and fluid consumption are affect on kidney stone, either increase or decrease its formation. Excessive animal products, grains consumption and as well as low water consumption and high intake of caffeine drinks was associated with stone incidence and recurrence. So assessments of dietary habits and development of dietary plan are considered the most important step of conservative management of kidney stones.

\section{Nursing implications and recommendations}

1- Drinking high amount of water more than two liters each day help to prevent recurrence and occurrence of kidney stones.

2- Decreasing consumption of Caffeine drinks like coffee, and tea have the same effect on stone prevention.

3- Intake low of animal protien (meats, poultry and fish) to less than $50 \mathrm{gm} /$ day can help to prevent kidney stone.

4- Maintaining low to moderate intake of grains per day to decrease total energy, obesity resulting in decrease kidney stone incidence.

5- Doing weight loss plan for overweight and obese patients to diminish the risk of stone formation.

Further recommendations:

1- Replication of the study on a large probability sample selected from different geographical area is recommended to obtain more generalized data.

2- Establish effective educational center about dietary therapy for patients with kidney stone. 


\section{Acknowledgment}

My deep appreciation and thanks also goes to all medical staff, nurses and kidney stones patients in El Kaser ElEiny Hospital for their co-operation and positive response.

\section{References}

[1]. Herfel, S., \& Schulsinger, D. A. (2015). Facts and Figures: Stones by the Numbers!. In Kidney Stone Disease (pp. 31-34). Springer International Publishing. Cloutier, J., Villa, L., Traxer, O., \& Daudon, M. (2015). Kidney stone analysis:“Give me your stone, I will tell you who you are!". World journal of urology, 33(2), 157-169.

[2]. Bose.A., Monk. R.D., Bushinsky.D.A., (2016). Kidney Stones. Williams Textbook. Endocrinology pp: $1365-1384$.

[3]. Turney, B. W., Appleby, P. N., Reynard, J. M., Noble, J. G., Key, T. J., \& Allen, N. E. (2014). Diet and risk of kidney stones in the

[4]. Oxford cohort of the Europea Prospective Investigation into Cancer and Nutrition (EPIC). European journal of epidemiology, 29(5),363-369.

[5]. de La Gueronniere V, Le Bellego L, Jimenez IB, Dohein O, Tack I, Daudon M. (2011). Increasing water intake by 2 liters reduces

[6]. cystallization risk indexes in healthy subjects. Arch Ital Urol Androl. 83:43-50

[7]. Hyams, E. S., Korley, F. K., Pham, J. C., \& Matlaga, B. R. (2011). Trends in imaging use during the emergency department evaluation of flank pain. The Journal of urology, 186(6), 2270- 2274.

[8]. Han, H., Segal, A. M., Seifter, J. L., \& Dwyer, J. T. (2015). Nutritional management of kidney stones (nephrolithiasis). Clinical nutrition research, 4(3), 137-152.

[9]. Brener, Z. Z., Winchester, J. F., Salman, H., \& Bergman, M. (2011). Nephrolithiasis: evaluation and management. Southern medical journal 104(2), 133-139.

[10]. Morgan, M. S., \& Pearle, M. S. (2016). Medical management of renal stones. BMJ, 352, i52.

[11]. Thuraisingham, R. C., \& Adu, D. (2009). Renal disease in the tropics. Manson's Tropical Diseases, 235.

[12]. Aggarwal, K. P., Narula, S., Kakkar, M., \& Tandon, C. (2013). Nephrolithiasis: molecular mechanism of renal stone formation and the critical role played by modulators.Bio Med research international.

[13]. Sigurjonsdottir, V. K., Runolfsdottir, H. L., Indridason, O. S., Palsson, R., \& Edvardsson, V. O. (2015). Impact of nephrolithiasis on kidney function. BMC nephrology, 16(1), 149.

[14]. Richman, K. A. T. H. E. R. I. N. E., O'Bell, J. O. H. N., \& Pareek, G. Y. A. N. (2014). The growing prevalence of kidney stones and opportunities for prevention. RI Med J, 97(12), 31-34.

[15]. Shang, W., Li, L., Ren, Y., Ge, Q., Ku, M., Ge, S., \& Xu, G. (2017). History of kidney stones and risk of chronic kidney disease: a meta-analysis. PeerJ, 5, e2907.

[16]. Noshad, H., Ahmadpour, F., Soltanpour, B., \& Ghojazadeh, M. (2014). Study of renal stones complications in 200 patients in Tabriz, Iran.Journal of Analytical Research in Clinical Medicine, 2(4)

[17]. Matt, V., \& Matthew, H., (2013). The retrospective chart review: important methodological considerations. Journal of educational evaluation for health professions, 10.

[18]. Halls, S., (2013). Applied Research Methods and Professional Development, $4^{\text {th }}$ ed. California, PP.30-39.

[19]. Michael, B., Larry,V., Hedges,H., Julian,P.,Higgins, R.., and Hannah, R., (2010). An Introduction to Statistical Power (Statistics in

[20]. Practice), $1^{\text {st }}$ ed.Campredge University Press,PP.43-45.

[21]. Sofia, N. H., \& Walter, T. M. (2016). PREVALENCE AND RISK FACTORS OF KIDNEY STONE. Global Journal For Research Analysis, 5(3).

[22]. Dai, M., Zhao, A., Liu, A., You, L., \& Wang, P. (2013). Dietary factors and risk of kidney stone: A case-control study in Southern

[23]. China. Journal of Renal Nutrition, 23(2), e21-e28.

[24]. UK Medical Research Council, (2011). The EPIC-Norfolk Food Frequency Questionnaire. Available at: www.srl.cam.ac.uk/epic/epicffq.

[25]. National Nutrition Institute,(2006). Food composition tables for Egypt" Cairo, Second edition.

[26]. Bae, S. R., Seong, J. M., Kim, L. Y., Paick, S. H., Kim, H. G., Lho, Y. S., \& Park, H. K. (2014). The epidemiology of reno-ureteral stone disease in Koreans: a nationwide population-based study. Urolithiasis, 42(2), 109-114.

[27]. Seitz, C., \& Fajkovic, H. (2013). Epidemiological gender-specific aspects in urolithiasis. World journal of urology, 31(5), 10871092.

[28]. Pfau, A., \& Knauf, F. (2016). Update on Nephrolithiasis: Core Curriculum 2016.American Journal of Kidney Diseases.

[29]. Khan, S. R., Pearle, M. S., Robertson, W. G., Gambaro, G., Canales, B. K., Doizi, S., ... \& Tiselius, H. G. (2017). Kidney stones.

[30]. Nature Reviews Disease Primers, 3, 17001.

[31]. Tasian, G. E., Kabarriti, A. E., Kalmus, A., \& Furth, S. L. (2017). Kidney stone recurrence among children and adolescents. The

[32]. Journal of urology, 197(1), 246-252.

[33]. Damasio, P. C., Amaro, C. R., Cunha, N. B., Pichutte, A. C., Goldberg, J., Padovani, C. R., \& Amaro, J. L. (2011). The role of salt abuse on risk for hypercalciuria. Nutrition journal, 10(1), 3.

[34]. Yoshimura, E., Sawada, S. S., Lee, I. M., Gando, Y., Kamada, M., Matsushita, M., ... \& Miyachi, M. (2016). Body Mass Index and

[35]. Kidney Stones: A Cohort Study of Japanese Men. Journal of Epidemiology, 26(3), 131-136.

[36]. Tracy, C. R., Best, S., Bagrodia, A., Poindexter, J. R., Adams-Huet, B., Sakhaee, K., ... \& Pearle, M. S. (2014). Animal protein andthe risk of kidney stones: a comparative metabolic study of animal protein sources. The Journal of urology, 192(1), 137-141.

[37]. Robertson, W. G. (2016). Dietary recommendations and treatment of patients with recurrent idiopathic calcium stone disease. Urolithiasis, 44(1), 9-26.

[38]. Frassetto, L., \& Kohlstadt, I. (2011). Treatment and prevention of kidney stones: an update. American family physician, 84(11), 1234.

[39]. Sorensen, M. D., Hsi, R. S., Chi, T., Shara, N., Wactawski-Wende, J., Kahn, A. J., ... \& Stoller, M. L. (2014). Dietary intake of fiber, fruit and vegetables decreases the risk of incident kidney stones in women: a Women's Health Initiative report. The Journal of urology, 192(6), 1694-1699.

[40]. Xu, C., Zhang, C., Wang, X. L., Liu, T. Z., Zeng, X. T., Li, S., \& Duan, X. W. (2015). Self-Fluid Management in Prevention of Kidney Stones: A PRISMA-Compliant Systematic Review and Dose-Response Meta-Analysis of Observational Studies. Medicine, 94(27).

[41]. Wang, J., Luo, G. T., Niu, W. J., Gong, M. M., Liu, L., Zhou, J., .. \& He, L. H. (2013). Risk factors for the kidney stones: a hospital- based case-control study in a distric hospital in Beijing]. Beijing da xue xue bao. Yi xue ban= Journal of Peking University. Health sciences, 45(6), 971-974. 
[42]. Ferraro, P. M., Taylor, E. N., Gambaro, G., \& Curhan, G. C. (2013). Soda and other beverages and the risk of kidney stones. Clinical Journal of the American Society of Nephrology, 8(8), 1389-1395.

[43]. Herrel, L., Pattaras, J., Solomon, T., \& Ogan, K. (2012). Urinary stone risk and cola consumption. Urology, 80(5), 990-994.

[44]. Guirguis-Blake, J. (2014). Preventing recurrent nephrolithiasis in adults. American family physician, 89(6), 461.

[45]. Pachaly, M. A., Baena, C. P., Buiar, A. C., De Fraga, F. S., \& Carvalho, M. (2015). Effects of non-pharmacological interventions on urinary citrate levels: a systematic review and meta-analysis. Nephrology Dialysis Transplantation, gfv303. 